\title{
Typhlodromips jurmoensis (Acari: Mesostigmata: Amblyseiinae), a new species from the archipelago of SW Finland
}

\section{Typblodromips jurmoensis (Acari: Mesostigmata: Amblyseiinae), новый вид с архипелага Юго-Западной ФинАяндии}

\author{
Wolfgang $\operatorname{Karg}^{1} \&$ Veikko Huhta ${ }^{2}$ \\ B. Карг ${ }^{1}$, В. Хухта ${ }^{2}$
}

\author{
${ }^{1}$ Hohe Kiefer 152, 14532 Kleinmachnow, Germany. \\ ${ }^{2}$ Department of Biological and Environmental Science, Box 35, 40014 Jyväskylä University, Finland. E-mail: v.huhta@pp.inet.fi. \\ (Corresponding author)
}

KEY WORDS: mite, new species, Phytoseiidae, Amblyseiinae.

КЛЮЧЕВЫЕ СЛОВА: клещ, новый вид, Phytoseiidae, Amblyseiinae.

ABSTRACT. A new species belonging to the genus Typhlodromips De Leon, 1965 is described. It was collected from Calluna moorland soil on Jurmo, a remote island in the SW archipelago of Finland. Typhlodromips herbarius (Wainstein, 1960) is considered a senior synonym of T. tenuis (Westerboer, 1963), syn.n. A key is given to related species with a similar spermathecal structure.

РЕЗЮМЕ. Описан новый вид рода Typhlodromips De Leon, 1965, собранный на вересковой пустоши на удалённом острове Юрмо в Юго-Восточном Архипелаге Финляндии. Приведен ключ для близких видов со сходной структурой сперматеки. Установлено, что Typhlodromips herbarius (Wainstein, 1960) является старшим синониммом T. tenuis (Westerboer, 1963), syn.n. Предложен ключ для определения видов со сходным типом сперматеки.

\section{Introduction}

The phytoseiid fauna of northern Europe is still poorly known, since new species can be found with only moderate effort. In Finland, Tuovinen [1993] reported 20 species in apple plantations and their surroundings. A comprehensive study on the soil fauna of Finland [Huhta et al., 2010] resulted in 11 new species for the country, 3 of which were previously undescribed [Karg \& Huhta, 2009]. A small sample of material collected from tree trunks [Huhta et al., 2012] included one more [Karg \& Huhta, 2012], and further collecting in the Finnish archipelago in 2012 yielded one more undescribed species. The latter species is described in the present paper.

Unlike in most other families of Gamasina, members of the family Phytoseiidae mainly occur in vegetation [Karg, 1993]. Similar to most new species detect- ed in the above studies, the type locality of the present species represents an unusual habitat for the family: soil of Calluna moorland.

According to the key of Karg [1993], the new species should be placed into the genus Amblyseius Berlese, 1904, subgenus Typhlodromips De Leon, 1965, but following the revision by Chant \& McMurtry [2006] we regard Typhlodromips as a separate genus. The shape of the female spermathecae was considered essential for the classification and identification of the species. Following the description of the new species, we present a key to distinguish it from related species with the same type of spermatheca, which we call the "herbarius species group" (despite the fact that neither herbarius nor tenuis were regarded as Typhlodromips by Chant \& McMurtry [2007])

\section{Material and methods}

We follow the nomenclature by Christian \& Karg [2008] in the chaetotaxy of the idiosoma, but since controversial opinions on the chaetotaxy exist, we present in Figs. 1 and 2 the optional nomenclature based on Lindquist \& Evans [1965], as applied by Chant \& Yoshida-Shaul [1989, 1991].

\section{Taxonomic survey \\ Typhlodromips jurmoensis sp.n.} Figs $1-2,3 \mathrm{~h}$.

TYPE. Holotype ${ }^{\circ}$ : FINLAND, Jurmo $\left(59^{\circ} 50^{\prime} \mathrm{N}, 21^{\circ} 13^{\prime} \mathrm{E}\right)$, Calluna moorland soil, August 2012 (V. Huhta), deposited in the Senckenberg Museum für Naturkunde Görlitz (SMNG), Germany.

DIAGNOSIS. Caudal setae of the dorsum remarkably short $(Z 5=77 \mu \mathrm{m}, Z 4=67 \mu \mathrm{m})$, shorter than $1 / 2$ the width of the idiosoma. Both anterior lateral setae $z 2$ and $\mathrm{z} 3$ longer than the reduced very short setae on the 


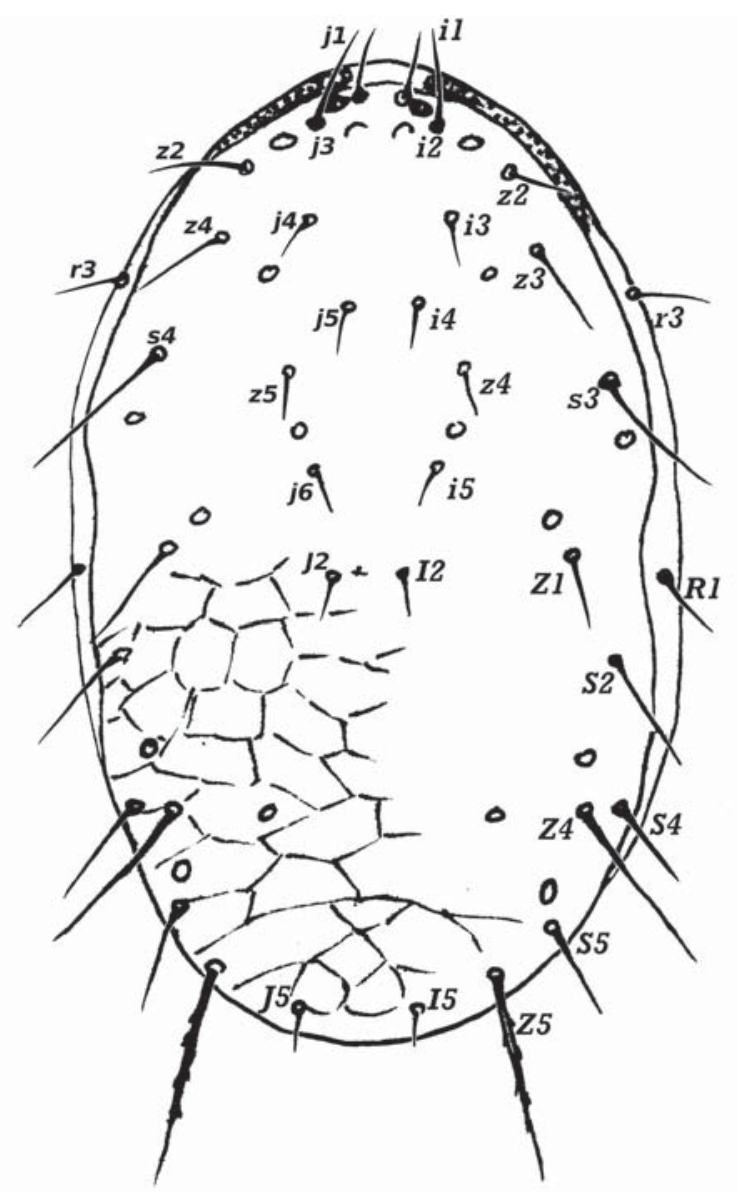

Fig. 1. Idiosomal dorsum of Typhlodromips jurmoensis sp.n. (holotype). On the right side the setal nomenclature by Christian \& Karg [2008], on the left that of Lindquist \& Evans [1965] and Chant \& Yoshida-Shaul [1989] (on the post-dorsum the nomenclature is identical except that $\mathrm{I} 2$ is used instead of $\mathrm{J} 2$, etc.).

Рис. 1. Дорзум Typhlodromips jurmoensis sp.n. (голотип). Справа терминология щетинок по Christian \& Karg [2008], слева - по Lindquist \& Evans [1965] и Chant \& Yoshida-Shaul [1989] (на пост-дорзуме обозначения идентичные, кроме J2, вместо которого использовано обозначение I2, и т.п.).

middle area of the dorsum, however $\mathrm{z} 3$ a little shorter than z2. Ventrianal shield slender, distinctly longer than wide. Spermatheca with saccular bell-shaped calyx (width : length $=3: 2$ ) and distinctly developed cervix $(=1 / 3$ the length of the calyx). Digitus mobilis of female chelicerae with one tooth, digitus fixus with four teeth.

DESCRIPTION (Figs 1, 2). Idiosoma $444 \mu \mathrm{m}$ long and $278 \mu \mathrm{m}$ wide.

Dorsum (Fig. 1) with 19 pairs of setae (r3, R1 on soft cuticle), dorsal shield without prominent waist, bearing 9 pairs of pore-like structures, prodorsum smooth, postdorsum with a net-like pattern, most setae of dorsum smooth and needle-like, only Z4 and Z5 finely feathered. Setae on the middle area of the dorsum (i3, i4, z4, i5, I2) remarkably short, only 11 to 14 $\mu \mathrm{m}$ long, marginal setae 25 to $56 \mu \mathrm{m}$ long, in detail: i1 = $25 \mu \mathrm{m}, \mathrm{i} 2=46 \mu \mathrm{m}, \mathrm{z} 2=39 \mu \mathrm{m}, \mathrm{z} 3=35 \mu \mathrm{m}, \mathrm{r} 3=25$ $\mu \mathrm{m}, \mathrm{R} 1=28 \mu \mathrm{m}$, shoulder setae $\mathrm{s} 3=56 \mu \mathrm{m}, \mathrm{Z} 1=42$ $\mu \mathrm{m}, \mathrm{S} 2=53 \mu \mathrm{m}, \mathrm{S} 4=35 \mu \mathrm{m}, \mathrm{S} 5=32 \mu \mathrm{m}$, caudal inner setae I5 $=12 \mu \mathrm{m}$ long, the caudal intermediate (in German: Zwischen-) setae Z4 $=67 \mu \mathrm{m}$ and Z5 $=77 \mu \mathrm{m}$ long. Peritremes extending to setae il.

Venter (Fig. 2a) with a smooth sternal shield, a little broader than long, bearing three pairs of setae and two pairs of lyrifissures, first and second sternal setae st1 and st $2=32 \mu \mathrm{m}, \mathrm{st} 3=28 \mu \mathrm{m}$ long. Posterior part of the genital shield $87 \mu \mathrm{m}$ wide, length : width of the shield nearly $4: 3$, genital setae $=30 \mu \mathrm{m}$ long. Ventrianal shield approximately pentagonal with rounded corners, broadest part at the level of setae Vi1; its width 119 $\mu \mathrm{m}$, length $143 \mu \mathrm{m}$, surface with a net-like pattern, behind setae Vi3 circular pores developed, preanal setae $(3$ pairs $)=32 \mu \mathrm{m}$, paranal setae and postanal seta ca. $22 \mu \mathrm{m}$ long, beside the ventrianal shield 3 pairs of setae: $=25-28 \mu \mathrm{m}$ long, caudal setae $\mathrm{Vz} 4=60 \mu \mathrm{m}$ long.

Spermatheca with bell-shaped calyx, $10 \mu \mathrm{m}$ long, at the opening $17 \mu \mathrm{m}$ wide, a distinctly visible tubularshaped cervix and a nodular-shaped atrium (Fig. 2c).

Chelicerae: digitus fixus with four teeth, digitus mobilis with one tooth, digitus mobilis $=34 \mu \mathrm{m}$ long.

Legs remarkably long, leg formula $=4123$, legs $\mathrm{I}=$ $440 \mu \mathrm{m}$, legs II $=357 \mu \mathrm{m}$, legs III $=340 \mu \mathrm{m}$, legs IV $=$ $444 \mu \mathrm{m}$ long, macrosetal chaetotaxy $=2,2,2,3$. Legs IV with remarkable macrosetae: at genu $49 \mu \mathrm{m}$, at tibia $46 \mu \mathrm{m}$, at tarsus $77 \mu \mathrm{m}$ long (Fig. 2b), macrosetae on

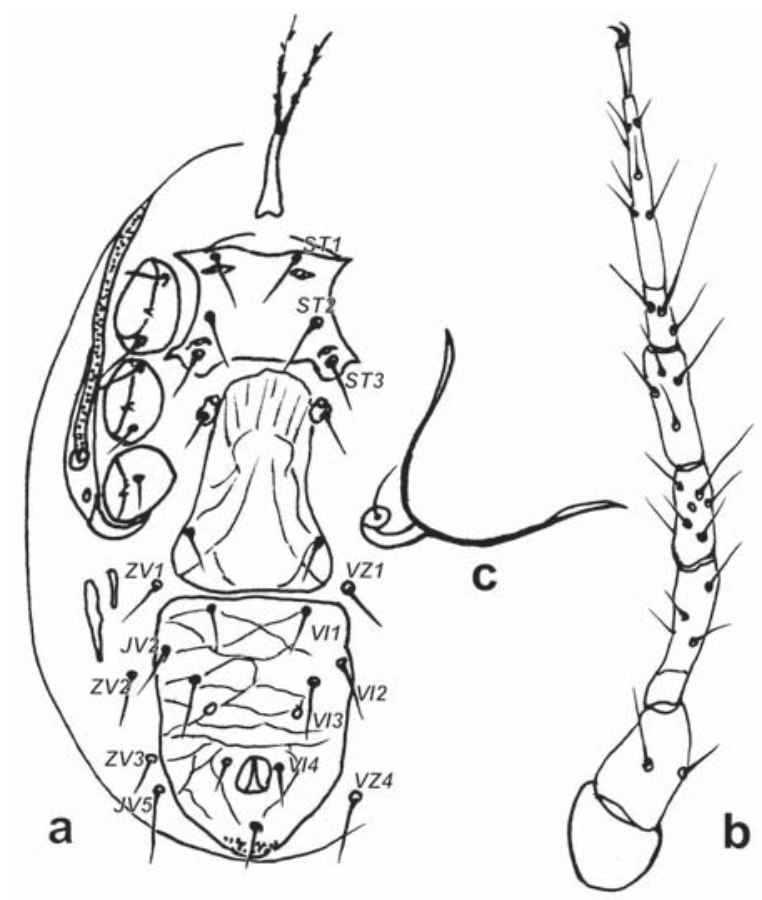

Fig. 2. Typhlodromips jurmoensis sp.n., female: a - idiosomal venter, b - leg IV, c - spermatheca. On the right side the setal nomenclature by Christian \& Karg [2008], on the left that of Lindquist \& Evans [1965] and Chant \& Yoshida-Shaul [1991].

Рис. 2. Typhlodromips jurmoensis sp.n., самка: a - вентральная поверхность идиосомы, b - нога IV, с - сперматека. Справа терминология щетинок по Christian \& Karg [2008], слева - по Lindquist \& Evans [1965] и Chant \& Yoshida-Shaul [1991]. 


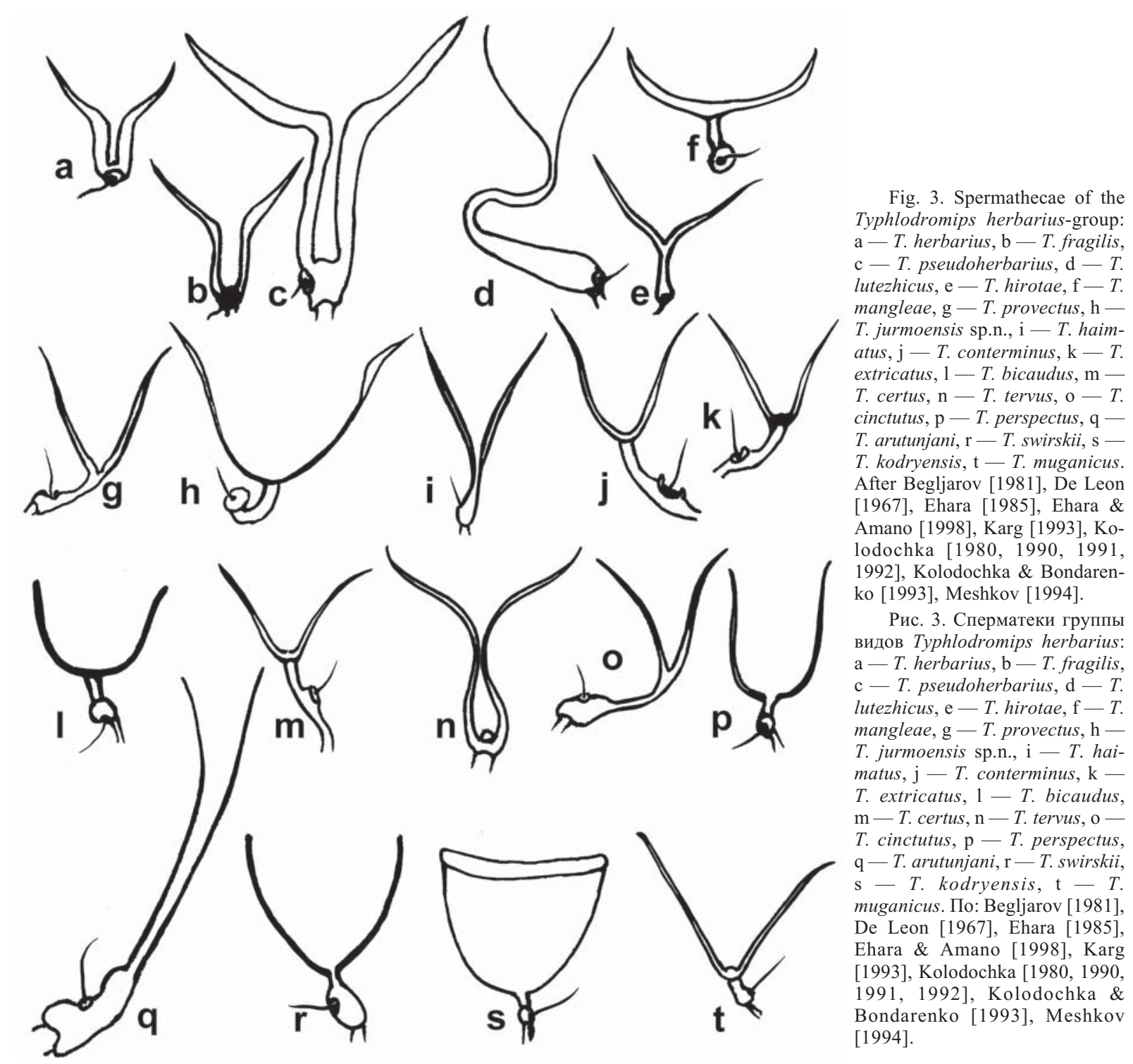

legs II: at genu $31 \mu \mathrm{m}$, at tibia $27 \mu \mathrm{m}$, at tarsus $36 \mu \mathrm{m}$ long, on legs III: at genu $36 \mu \mathrm{m}$, at tibia $34 \mu \mathrm{m}$, at tarsus $36 \mu \mathrm{m}$ long, relevant chaetotactic patterns of genu II have the formula: $2-2 / 0,2 / 0-1$; of genu III the formula: $1-2 / 0,2 / 1-1$.

ETYMOLOGY. We name the new species Typhlodromips jurmoensis after Jurmo, a remote island in the SW archipelago of Finland. This island is well known to naturalists and represents the outmost end of the ridge Salpausselkä, a formation created by melting ice at the end the Ice Age and extending from the SW across the south of Finland.

\section{Taxonomy}

We have placed the new species into the genus Typhlodromips, following the definition of De Leon [1965], not of Karg [1993], Chant \& McMurtry [2006, 2007], namely: dorsal setae needle-like, setae on the middle region of the dorsum distinctly reduced in length, caudal setae Z5 relatively short, length not more than approximately $1 / 2$ the width of the dorsum, setae $Z 4$ and Z5 finely feathered, ventrianal shield pentagonal or more triangular, anterior region broader than the posterior region or equal in width, with four to five pairs of setae.

In our opinion, the key of Chant \& McMurtry [2006] contains uncertain formulations, such as "GeIII rarely with a macroseta", "fixed digit of chelicerae usually with more than 6 teeth" etc. Moreover, in Chant \& McMurtry [2007]: "Genu II and III, and often genu I with macroseta,..." and "fixed digit of chelicerae with 8-11 or more teeth...". These features vary from species to species and are therefore unsuitable as differential diagnoses of taxonomic groups above the species level. In the following key we include the species of Typhlodromips sensu De Leon, 1965, with "complete" spermatheca: distinctly developed cervix (neck), calyx 
and atrium (Fig. 5a-t), as distinct from those species with no visible cervix. This is done without regard to the fact that Chant \& McMurtry [2006] placed these species into several different genera. We call this group the "herbarius species group".

NOTE. For spermatheca terminology we follow Begljarov [1981] and Karg [1991]. Muma \& Denmark [1970] and Denmark \& Muma [1989] did not distinguish between the calyx and cervix.

\section{KEY TO THE “HERBARIUS SPECIES GROUP”}

1 (6) Neck of spermatheca remarkably broad (Figs 3a,b,c).

2 (5) Neck nearly as long as calyx or shorter (Figs 3a,b).

3 (4) Neck shorter than calyx (Fig. 3a): T. herbarius (Wainstein, 1960), Syn.n.: T. tenuis (Westerboer, 1963)*) Europe, on litter, grass, herbs and shrubs.

4 (3) Neck nearly as long as calyx (Fig. 3b): T. fragilis Kolodochka et Bondarenko, 1993 - Ukraine, on herbs of steppes.

5 (2) Neck $=1 \frac{1}{2} \mathrm{x}$ as long as calyx (Fig. 3c): T. pseudoherbarius (Meshkov, 1994) - Tuva, on herbs.

6 (1) Neck of spermatheca slender, not remarkably broad.

7 (8) Neck remarkably long, as long as calyx (Fig. 3d), length of Z5:Z4=3:2: T. lutezhicus (Wainstein, 1972) - Ukraine, Armenia, on the ground.

8 (7) Neck not so long.

9 (12) Neck $=1 / 2$ the length of calyx (Fig. 3 e, f), caudal setae $Z 5=2 \times$ the length of $Z 4$.

10 (11) Setae Z4, S2, S4 and S5 nearly equal in length: $T$. hirotae Ehara, 1985 - Japan, on grass of sand-dunes

11 (10) Setae S2, S4 and S5 extremely reduced in length, 1/ 3 the length of Z4: A. mangleae De Leon, 1967 Caribbean area, Brazil, Peru, on mangroves.

12 (29) $\mathrm{Neck}=1 / 5$ to $1 / 3$ the length of calyx.

13 (22) Neck $=$ approximately $1 / 3$ the length of calyx (Fig. $3 \mathrm{~g}-\mathrm{k})$.

14 (15) Caudal setae Z5 remarkably long, $2 x$ the length of Z4: T. provectus Kolodochka, 1991 - Ukraine, Russia, on reed, vine shoots and shrubs.

15 (14) Caudal setae Z5 not remarkably longer than Z4.

16 (17) Caudal setae $Z 5=77 \mu \mathrm{m}, \mathrm{Z} 4=67 \mu \mathrm{m}$ long: $T$. jurmoensis sp.n. - Finland, in moorland soil.

17 (16) Caudal setae Z5 and Z4 shorter.

18 (21) Caudal setae Z5 and Z4 of medium length (34 to 58 $\mu \mathrm{m})$.

19 (20) Caudal setae $\mathrm{Z} 5=58 \mu \mathrm{m}, \mathrm{Z} 4=47 \mu \mathrm{m}$ long: $T$. haimatus Ehara, 1967 - Japan, on conifers.

20 (19) Caudal setae Z5 = 46-51 $\mu \mathrm{m}, \mathrm{Z} 4=34-37 \mu \mathrm{m}$ long: T. conterminus Kolodochka, 1990 - Ukraine, Uzbekistan, Israel, Arabia, alpine Caucasus.

21 (18) Caudal setae Z5 and Z4 remarkably short: Z5 $=40$, Z4 $=27-29 \mu \mathrm{m}$. long: T. extricatus Kolodochka, 1991 — Ukraine, Armenia.

*) The authors of $T$. herbarius and $T$. tenuis did not investigate the spermathecae. Karg [1971] was the first to publish a drawing of the spermatheca of $T$. tenuis, Begljarov [1981] was the first to publish a drawing of the spermatheca of $T$. herbarius. The present extensive comparisons resulted in the conclusion that the spermathecae of both these species are identical. Furthermore, both species show the same proportions of dorsal setae length and shape of the ventrianal shield. Hitherto, the species were documented as separate taxa, in Middle Europe by Karg [1991, 1993] and Tuovinen [1993], in East Europe by Kolodochka \& Bondarenko [1993] and Meshkov [1994].
22 (13) $\mathrm{Neck}=1 / 5$ to $1 / 4$ the length of calyx (Fig. 31-0), caudal setae Z5 remarkably long, $1 \frac{1}{2}$ to 2 times the length of Z4 or slightly longer.

23 (24) Spermatheca cup-like: T. bicaudus Wainstein, 1962 - Europe, Middle Asia, in litter, on herbs and deciduous trees.

24 (23) Spermatheca shaped like a funnel (Fig. 3m-o).

25 (26) Neck and calyx separated distinctly: T. certus Kolodochka, 1990 - Ukraine, Uzbekistan, soil of steppe and alpine Caucasus.

26 (25) Neck gradually proceeding to calyx (fig 3n, o).

27 (28) Calyx remarkably wide (Fig. 3n): T. tervus (Meshkov, 1994) - Russia, steppe.

28 (27) Calyx nearly as long as wide (Fig. 3o): T. cinctutus Livshitz et Kuznetsov, 1972 - Russia, on ivy and bindweed.

29 (12) Neck very short, length of neck: length of calyx = 1 : 12 to $1: 10$

30 (33) Calyx longer than wide (Figs 3p, q).

31 (32) Calyx twice as long as wide: T. perspectus Kolodochka, 1992 - Ukraine, grass and herbs of steppes.

32 (31) Calyx four times as long as wide (Fig. 3q): $T$. arutunjani Wainstein et Begljarov, 1971 - Russia, on grass and shrubs.

33 (30) Calyx shorter than wide.

34 (37) Calyx cup-like and somewhat shorter than wide (Fig. 3r, s).

35 (36) Digitus fixus with 7 to 10 teeth, digitus mobilis with 3 teeth, caudal setae Z5 $=102-118 \mu \mathrm{m}$ long: $T$. swirskii Athias-Henriot, 1962 - Italy, Turkey, Egypt, Israel, Yemen, Georgia, Azerbaijan, deciduous trees (Prunus).

36 (35) Digitus fixus with 4 teeth, digitus mobilis with one tooth, caudal setae $\mathrm{Z} 5=80 \mu \mathrm{m}$ long: $T$. kodryensis Kolodochka, 1980 - Moldova, on herbs and grass.

37 (34) Calyx funnel-like and nearly $11 / 2 \mathrm{x}$ as wide as long (Fig. 3t): T. muganicus Abbasova, 1970 - Azerbaijan, nest of vole.

ACKNOWLEGEMENTS. We thank Olga Makarova (Moscow) for valuable corrections of the manuscript. English of the final draft was checked and edited by David Penney (Manchester).

\section{References}

Begljarov G.A. 1981. [Phytoseiid mites (Parasitiformes, Phytoseiidae) of Soviet Union] // Informatsionnyi Byulleten' Wostochno-Palearkticheskaya Sektsiya Mezhdunarodnoi Organizatsii Biologicheskoi Bor'by. Leningrad. Vol.1. No.2: 7-95; No.3. P.6-44 [in Russian].

Chant D.A., McMurtry J.A. 2006. A review or the subfamily Amblyseiinae Muma (Acari: Phytoseiidae): Part IX. An overview / / International Journal of Acarology. Vol.32. P.125-152.

Chant D.A., McMurtry J.A. 2007. Illustrated keys and diagnoses for the genera and subgenera of the Phytoseiidae of the World (Acari: Mesostigmata). Indira Publishing House, West Bloomfield. $220 \mathrm{pp}$.

Chant D.A., Yoshida-Shaul E. 1989. Adult dorsal setal patterns in the family Phytoseiidae (Acari: Gamasina) // International Journal of Acarology. Vol.15. P.219-233.

Chant D.A., Yoshida-Shaul E. 1991. Adult ventral setal patterns in the family Phytoseiidae (Acari: Gamasina) // International Journal of Acarolology Vol.17. P.187-199.

Christian A., Karg W. 2008. A revised setal nomenclature based on ontogenetic and phylogenetic characters and universally applicable to the idiosoma of Gamasina (Acari, Parasitiformes) // Soil Organisms. Vol.80. P.45-79. 
De Leon D. 1965. Phytoseiid mites from Puerto Rico with descriptions of new species (Acarina: Mesostigmata) // The Florida Entomologist. Vol.48. P.121-131.

De Leon D. 1967. Some mites of the Caribbean Area. Lawrence, Kansas, USA: Allen Press Inc. 60 pp.

Denmark H.A., Muma M.H. 1989. A revision of the genus Amblyseius Berlese, 1914 // Occasional papers of the Florida State Collection of Arthropods. Vol.4. P.1-149.

Ehara S. 1985. Five species of Phytoseiid mites from Japan with descriptions of two new species (Acarina, Phytoseiidae) // Zoological Science. Vol.2. P.115-121.

Ehara S., Amano H. 1998. A revision of the family Phytoseiidae in Japan (Acari, Gamasina), with remarks on its biology // Species Diversity. Vol.3. P.25-73.

Huhta V., Siira-Pietikäinen A., Penttinen R., Räty M. 2010. Soil fauna of Finland: Acarina, Collembola and Enchytraeidae // Memoranda Soc. Fauna Flora Fennica. Vol.86. P.59-82.

Huhta V., Siira-Pietikäinen A., Penttinen R. 2012. Importance of dead wood for soil mite (Acarina) communities in boreal oldgrowth forests // Soil Organisms. Vol.84. P.499-512.

Karg W. 1971. Acari (Acarina) Milben, Unterordnung Anactinochaeta (Parasitiformes). Die freilebenden Gamasina (Gamasides) Raubmilben // Tierwelt Deutschlands. Jena: Gustav Fischer Verlag. Lfg.59. $475 \mathrm{~S}$.

Karg W. 1991. Die Raubmilbenarten der Phytoseiidae Berlese (Acarina) Mitteleuropas sowie angrenzender Gebiete // Zoologische Jahrbücher, Systematik. Bd.118. S.1-64.

Karg W. 1993. Acari (Acarina) Milben, Parasitiformes (Anactinochaeta) Cohors Gamasina Leach: Raubmilben, 2. überarbeitete Auflage // Tierwelt Deutschlands. Lfg.59. Jena, Stuttgart, New York. $523 \mathrm{~S}$

Karg W., Huhta V. 2009. Taxonomic remarks on Phytoseiidae Berlese (Acari: Mesostigmata), with description of three new species from Finland // International Journal of Acarology. Vol.35. P.511-520.
Karg W., Huhta V. 2012. Amblyseius fennicus sp. n. (Acarina, Gamasina: Phytoseiidae) from Finland, with a key to the $A$. americanus group // Entomologica Fennica. Vol.23. P.193-198.

Kolodochka L.A. 1980. [New mites (Parasitiformes Phytoseiidae) from Moldavia] // Vestnik zoologii, Kiev. No.4. P.39-45 [in Russian].

Kolodochka L.A. 1990. [Three new Phytoseiid mite species (Parasitiformes)] // Novosti faunistiki i sistematiki. Kiev: Naukova dumka. Vol.44. P.158-163 [in Russian].

Kolodochka L.A. 1991. [New mite species of genus Amblyseius (Parasitiformes Phytoseiidae)] // Vestnik zoologii, Kiev. No.3. P.17-26 [in Russian].

Kolodochka L.A. 1992. [A new subgenus and two new species of the family Phytoseiidae (Parasitiformes) from the Ukraine] // Vestnik zoologii, Kiev. No.2. P.20-25 [in Russian].

Kolodochka L.A., Bondarenko L.V. 1993. [The plant dwelling Phytoseiid mites of the black sea reserve, with description of two new species] // Vestnik Zoologii, Kiev. No.4. P.32-38 [in Russian].

Lindquist E.E., Evans G.O. 1965. Taxonomic concepts in the Ascidae, with a modified setal nomenclature for the idiosoma of the Gamasina (Acarina: Mesostigmata) // Memoranda of the Entomological Society of Canada. Vol.47. P.1-64.

Meshkov Yu.I. 1994. [Two new species of mites of the genus Neoseiulus (Parasitiformes Phytoseiidae) from Russia] // Zool. Zhurn. Vol.73. No.5. P.108-111 [in Russian].

Muma M.H., Denmark H.A. 1970. Phytoseiidae of Florida // Arthropods of Florida and neighbouring land areas. Gainesville. Vol.6. $150 \mathrm{pp}$.

Tuovinen T. 1993. Identification and occurrence of phytoseiid mites (Gamasina: Phytoseiidae) in Finnish apple plantations and their surroundings // Entomologica Fennica. Vol.31. P.95-114.

Responsible editor Yu.M. Marusik 